\title{
Assessment of nasopharynx area and level of severity posterior crossbite on children with cleft lips and palate post- palatoplasty
}

\author{
Anie Apriani ${ }^{1 *}$, Risti Saptarini², Alwin Kasim³ ${ }^{3}$ Fahmi Oscandar ${ }^{4}$ \\ 'Department of Pediatric Dentistry, Faculty of Dentistry Maranatha Christian University, Indonesia \\ ${ }^{2}$ Department of Pediatric Dentistry, Faculty of Dentistry Universitas Padjadjaran, Indonesia \\ ${ }^{3}$ Department of Oral and Maxillofacial Surgery, Faculty of Dentistry Universitas Padjadjaran, \\ Indonesia \\ ${ }^{4}$ Department of Dentomaxillofacial Radiology, Faculty of Dentistry Universitas Padjadjaran, \\ Indonesia
}

\begin{abstract}
Introduction: Many children with post palatoplasty had crossbite posterior. This study was aimed to assess the nasopharynx area and the posterior crossbite severity level of children with cleft lip and palate (CLP) who received palatoplasty treatment compared to normal children. Methods: The study was observational analytic. The research subject was 14 children with CLP post-palatoplasty and 14 normal children. The object of research was 28 study models and secondary data of lateral cephalometric radiograph of children with CLP post palatoplasty and normal children. The measurement of PTMad1-Ad2-PTM and PTM-So-Ba-PTM were used to measure the nasopharyngeal area. Study models were assessed to analyse the level of severity of posterior crossbite. Results: The average of the soft tissues (the nasopharynx) area children with CLP post-palatoplasty was $35.02 \mathrm{~mm}^{2}$, which was lower than the normal child $\left(35.73 \mathrm{~mm}^{2}\right)$. Similarly, the average of the hard tissues (the nasopharynx) area children with CLP post-palatoplasty was $301.40 \mathrm{~mm}^{2}$, which was smaller than the normal children $\left(315.54 \mathrm{~mm}^{2}\right)$. Statistical analysis of the nasopharynx area resulted in non-significant difference. All children with CLP post-palatoplasty was suffered from posterior crossbite. The level of severity posterior crossbite, which was categorised as good was $42.9 \%$, poor criteria was $35.7 \%$, moderate criteria was $14.3 \%$, and very good criteria was $7.1 \%$. Conclusion: There is no difference between the average size of the nasopharynx area on children with CLP post-palatoplasty and normal children. The level of severity posterior crossbite after palatoplasty in CLP children mostly included in the good criteria.
\end{abstract}

Keywords: Nasopharynx, posterior crossbite, palatoplasty.

p-ISSN: 1979-0201; e-ISSN: 2549-6212; Available from: http://jurnal.unpad.ac.id/pjd/article/view/17951

DOI: 10.24198/pjd.vol32no2.17951

Submission: Jul 24, 2018; Accepted: Jul 30, 2020; Published online: Jul 31, 2020

"Corresponding author: Anie Apriani, Department of Pediatric Dentistry, Faculty of Dentistry Maranatha Christian University, Indonesia. Department of Pediatric Dentistry, Faculty of Dentistry Maranatha Christian University, 65, Jalan Surya Sumantri, Bandung, West Java, Indonesia, 40164. Phone: +628164872941; Email: anieapriani25@gmail.com 


\section{INTRODUCTION}

Cleft lip and palate (CLP) is one of the craniofacial disorders that often occur. Although there have been many improvements and treatments for children with CLP abnormalities that occur will continue. From birth to adolescence, children with CLP experience growth and development, including aesthetics, function, and psychosocial must be balanced during treatment. ${ }^{1,2}$ The incidence of cleft lip with or without cleft palate in the United States was 1 in 2,000 births. The incidence of CLP abnormalities when seen based on ethnicity in every 1000 births shows in Indian ethnicity was 3.6 , Asian ethnicity was 2.1 , white ethnicity was 1.0 , and black ethnicity was 0.41 . Otherwise, the incidence of cleft palate does not differ much across all ethnicities, which was 0.5 out of 1,000 births. Incidence based on sex, male and female was 2: 1 for cleft lip with or without cleft palate and 1: 2 for cleft palate only. ${ }^{1}$

Children who suffer from CLP in Indonesia are quite often found, although there are not enough data to support the number of CLP events in Indonesia. The number of untreated CPL sufferers in Indonesia reaches 5,000-6,000 cases per year, estimated can increase 6,000-7,000 cases per year. ${ }^{3}$ One of the government's efforts to handle CLP abnormalities is establishing the Cleft Center. One of the Cleft Center is becoming the part of Universitas Padjadjaran Dental Hospital Bandung, which has been actively treating and rehabilitating children with CLP patients. ${ }^{4}$

Cleft lip and palate (CLP) are abnormalities that occur during embryology. The disorder occurs at the age of the first trimester intrauterine of content that interferes with the process of fetal growth and development. CLP was a congenital abnormality in the form of gaps in the lips, gums, and palate. It was an imperfect development of the lips and palate when the fetus was formed. The impact of the failure of the union of the nose and jaw-forming facial protrusions in the fifth week of pregnancy can result in abnormalities of the nasopharynx and unification of the maxillary protrusions. ${ }^{5}$ Also, it causes various other disorders such as aesthetics, speech disorders, hearing and malocclusion caused by tooth loss, shape and malposition of teeth. ${ }^{3,5}$
The treatment for children suffered from CLP was carried out comprehensively, one of which was by performing labioplasty and palatoplasty. Both of the surgery labioplasty and palatoplasty have a purpose of restoring function and correcting the abnormalities caused by the cleft lip and palate. Side effect improvements in function and improvement of these abnormalities, palatoplasty surgery affect maxillary growth. ${ }^{2,6}$ The study by Shi et al. ${ }^{6}$ stated that after the patient was operated on, there was a possibility of maxillary hypoplasia, so the facial profile becomes concave, and there was a defect in the dental arch. Nevertheless, surgery was absolutely necessary to correct the abnormality. Palatoplasty surgery also affects the upper respiratory tract. Respiratory disorders that often occur in children with CLP in the form of abnormalities in the upper airway consisting of the nose, pharynx, and larynx. One such disorder was a reduction in the structure of the nasopharynx bone associated with the location of the nasopharynx more posteriorly and late maxillary growth. Nasopharynx airway that shrinks was closely related to reducing the size of the nasopharynx bone structure. ${ }^{7}$

Gohilot et al. ${ }^{8}$ mentioned that a reduction in the nasopharynx area was accompanied by a decrease in lateral and vertical maxillary growth after palatoplasty surgery, which can be determined by nasopharynx examination through lateral cephalometric radiograph analysis in postpalatoplasty. ${ }^{8}$ Reduction of nasopharynx area was one of the factors in the occurrence of a posterior crossbite that cannot be seen clinically, but can be measured by performing radiographic assessments using radiographic analysis lateral cephalometry as a routine diagnostic tool in determining orthodontic cases and for assessing nasopharynx area. ${ }^{9}$ Huddart and Bodenham explained that the measurement of a posterior crossbite in the primary teeth of CLP children after palatoplasty can be done quite easy. ${ }^{10}$ The measurement used the frequency and various posterior crossbite patterns in a study model. ${ }^{10}$ The severity of posterior crossbites is determined by scoring the study model by assessing the relationship of first and second primary molars on both sides using the Huddart Bodenham scale expressed on a numerical scale (scale of -3 to +1$).{ }^{10}$ Each maxillary tooth 
was assessed based on its relationship with the mandible. Craniofacial growth is an essential key to assessing the outcome of the care of children with CBL post palatoplasty. Good craniofacial growth results in a good dental arch and treatment can be carried out conventionally. ${ }^{10}$

Based on the observations of researchers while on duty at the Cleft Center Bandung, many found children with CLP who had palatoplasty surgery had posterior crossbite. This study was aimed to assess the nasopharynx area and the posterior crossbite severity level of children with cleft lip and palate (CLP) who received palatoplasty treatment compared to normal children. The study was conducted on CLP children after palatoplasty during the deciduous tooth period with the aim that before posterior crossbite abnormalities are discovered, the faster the treatment can be carried out and the problem of malocclusion can be reduced in the future.

\section{METHODS}

The research design used was analytic observational. Subjects consisted of postpalatoplasty cleft lip and palate children and normal children aged 4 to 6 years. The examination was carried out using a lateral cephalometric radiograph digital using software Ep x Impla (Vatech, Korea) and a study model in pediatric patients with CLP post-palatoplasty and normal children as research objects. Research has been submitted for application of ethics to the Health Research Ethics Commission of Universitas Padjadjaran and the submission of a permit letter to the Director of Universitas Padjadjaran Dental Hospital and the head of the Cleft Center which was within the scope in Universitas Padjadjaran Dental Hospital which was the chosen place for research. Data collection for CLP children was conducted at Cleft Center of Universitas Padjadjaran Dental Hospital and also from normal children. Research subjects were collected and selected according to research criteria, and parents had completed informed consent sheets.

The total population was 40 children with CLP post-palatoplasty. Fourteen children with CLP post-palatoplasty who met the inclusion criteria and fourteen normal children were taken as the study sample. The inclusion criteria for children with CLP post-palatoplasty were as follows: children with a complete initial diagnosis of cleft lip and palate, willing to participate in the study. Criteria for intra-oral conditions were children with a period of deciduous teeth, have never been treated orthodontically and able to be taken dental moulds. Children with mixed or permanent teeth could not participate in the study.

Measurements were made on the broad nasopharynx of CLP children and normal children who had done lateral cephalometric photographs. The measured nasopharynx airway area was measured by the measurement of the reference radiographs (Ptm- $\left.\mathrm{ad}_{1}-\mathrm{ad}_{2}-\mathrm{Ptm}\right)$ and (Ptm-Ba-So$\mathrm{Ptm})$ measured by the distance of Ptm- $\mathrm{ad}_{1}, \mathrm{ad}_{1}$ $\mathrm{ad}_{2}, \mathrm{ad}_{2}-$ Ptm and Ptm-Ba, Ba-So, So-Ptm on a numerical scale with units $(\mathrm{mm})$ which were then referred to as soft-tissue lines and nasopharyngeal network lines. Determination of the area of soft tissue (Ptm- $\left.\mathrm{ad}_{1}-\mathrm{ad}_{2}-\mathrm{Ptm}\right)$ and the hard tissue (PtmBa-So-Ptm) of the nasopharynx was calculated using the triangular formula The Heron theorem expressed in numerical scale expressed in $\mathrm{mm}^{2} .^{11}$ As for the posterior crossbite measurement was performed where there was an abnormality of the location and position of the tooth in the buccal-lingual or labio-lingual relationship at the posterior part of the maxillary and mandibular teeth. The severity of the posterior crossbite severity was determined by scoring the study model by assessing the first and second first molars of both sides using the Huddart Bodenham scale expressed on a numerical scale (scales -3 to +1 ). ${ }^{12}$

\section{RESULTS}

The respondents were children aged 4 to 6 years, consisted of boys and girls. Children with CLP post-palatoplasty consisted of 4 girls (29\%) and 10 boys $(71 \%)$, while normal children consisted of 9 girls $(64.3 \%)$ and 5 boys (35.7\%). The average age of children with CLP post-palatoplasty was 4 years 3 months, and normal children was 4 years 6 months (Table 1).

Results of extensive measurements of soft and hard nasopharynx tissue in children with CLP post-palatoplasty and normal children showed that the average rate of soft and hard nasopharynx tissue in children with CLP post-palatoplasty was lower than normal children. Children with CLP 
Table 1. Distribution of respondents based on age (average) and sex of CLP children and normal children

\begin{tabular}{ccc}
\hline Criteria & CLP & Normal \\
\hline Age (average) & 4 years 3 months & 4 years 6 months \\
\hline Gender & & \\
\hline (boy) & $10(71 \%)$ & $5(35.7 \%)$ \\
(girl) & $4(29 \%)$ & $9(64.3 \%)$ \\
\hline Total & $14(100 \%)$ & $14(100 \%)$ \\
\hline
\end{tabular}

post-palatoplasty had a broader average of soft nasopharynx tissue as of $35.02 \mathrm{~mm}^{2}$, which was smaller than normal children $\left(35.73 \mathrm{~mm}^{2}\right)$. As well as likewise, the average area of nasopharynx hard tissue in children with CLP post-palatoplasty had an area of $301.40 \mathrm{~mm}^{2}$, which was smaller than the normal child $\left(315.54 \mathrm{~mm}^{2}\right)$ (Table 2).

Table 2. Average nasopharynx area

\begin{tabular}{ccc}
\hline Subject & $\begin{array}{c}\text { Ptm-ad }-\mathrm{ad}_{2} \text {-Ptm Area } \\
\left(\mathrm{mm}^{2}\right)\end{array}$ & $\begin{array}{c}\text { Ptm-So-Ba-Ptm Area } \\
\left(\mathrm{mm}^{2}\right)\end{array}$ \\
\hline $\begin{array}{c}\text { CLP post } \\
\text { palatoplasty }\end{array}$ & 35.02 & 301.40 \\
\hline Normal & 35.73 & 315.54 \\
\hline
\end{tabular}

Advance measurements were made on the study model using the Huddart and Bodenham scoring methods. ${ }^{12}$ The first study model scoring was performed on the entire tooth including the anterior teeth, then the scores were grouped into five severity groups. Crossbite scoring results which were included in the very good criteria was found in no CLP post palatoplasty children, as the most common criteria found was the poor criteria (42.9\%) (Table 3).

Table 3. Level of severity of crossbite in children with CLP

\begin{tabular}{ccc}
\multicolumn{3}{c}{ post palatoplasty } \\
\hline Criteria & Score & $\begin{array}{r}\text { Total CLP post palatoplasty } \\
\text { (child) (\%) }\end{array}$ \\
\hline Very poor & $-30-(-23)$ & $2(14.3)$ \\
Poor & $-22-(-15)$ & $6(42.9)$ \\
Moderate & $-14-(-7)$ & $5(35.7)$ \\
Good & $-6-1$ & $1(7.1)$ \\
Very good & $2-10$ & $0(0)$ \\
\hline Total & & $14(100)$
\end{tabular}

Further study model scoring was conducted to screen for a posterior crossbite. The scored teeth include maxillary and mandibular teeth, which were assessed as occlusion of 55/85, 54/84,
$64 / 74$ and $65 / 75$ teeth. The degree of severity of posterior crossbite in children with CLP post palatoplasty was grouped into five severity groups: very severe, poor, moderate, good, and very good. The results of posterior crossbite scores which included in the very poor criteria was not found in children with CLP post palatoplasty, where most criteria found was the good criteria (42.9\%). It means children with CLP post palatoplasty had good criteria (Table 4).

Table 4. Severity of posterior crossbite in children with CLP post-palatoplasty

\begin{tabular}{ccc}
\hline Criteria & Score & $\begin{array}{c}\text { Total CLP Post-palatoplasty } \\
\text { (child) (\%) }\end{array}$ \\
\hline Very poor & $-12-(-10)$ & $0(0)$ \\
Poor & $-9-(-7)$ & $2(14.3)$ \\
Moderate & $-6-(-4)$ & $5(35.7)$ \\
Good & $-3-(-1)$ & $6(42.9)$ \\
Very good & $0-4$ & $1(7.1)$ \\
\hline Total & & $14(100)$ \\
\hline
\end{tabular}

The difference in the average nasopharynx and posterior crossbite values in children with CLP post-palatoplasty with normal children was statistically analysed with t-test.

The result of statistical analysis of the difference of the average value of nasopharynx soft tissue of children with CLP post palatoplasty with normal children was not significant ( $\mathrm{p}$-value $=0.449$ ) (Table 5).

Table 5. Differences in mean average values of nasopharyngeal soft tissue

\begin{tabular}{lcccc}
\hline \multicolumn{1}{c}{ Subject } & $\mathrm{N}$ & Mean & Std. dev & p-value \\
\hline CLP & 14 & 35.02 & 14.25 & \\
Normal & 14 & 35.73 & 14.84 & 0.449 \\
\hline
\end{tabular}

The result of statistical analysis about the difference between the average value of nasopharynx hard tissue of children with CLP post palatoplasty with normal children was not significant $(p$-value $=0.306)($ Table 6$)$.

Table 6. Differences in the average value of nasopharynx hard tissue

\begin{tabular}{lcccc}
\multicolumn{5}{c}{ hard tissue } \\
\hline Subject & $\mathrm{N}$ & Mean & Std.dev & $\mathrm{p}$-value \\
\hline CLP & 14 & 301.40 & 61.13 & 0.306 \\
Normal & 14 & 315.54 & 8317 & \\
\hline $\mathrm{P}<0.05$ & & &
\end{tabular}




\section{DISCUSSION}

In this study, children with CLP post-palatoplasty were more likely to be suffered by boys (10 children) than girls (4 children) (see Table 1), following the study conducted by Leslie et al. ${ }^{13}$ study which mentioned that cleft lip and palate occur around twice as often in boys as girls, whereas cleft lip sufferers were reported more in girls. The research of Carroll et al. ${ }^{14}$ found that children born with CLP were estimated to be 60$80 \%$ male, similar to the results of the present study which showed that $71 \%$ of children with CLP were boys.

The wide-ranging difference between soft and hard tissue nasopharynx in children with CLP post palatoplasty has a smaller area than normal children (see Table 2). The results concurred with Wermker et al. ${ }^{7}$ which cites the wideranging nasopharynx of children with CLP postpalatoplasty with normal children. This opinion was consistent with Gohilot ${ }^{8}$ stated that there was a reduction in nasopharynx extent accompanied by slowing of lateral and vertical maxillary growth in CLP children after palatoplasty. The widespread reduction of the nasopharynx in children with CLP post-palatoplasty was due in part to the growth that since embryology has been impaired, also unavoidably due to palatoplasty surgery. This condition results from scar tissue formed after palatoplasty resulting in muscle contracture of the levator veli palatini. ${ }^{15}$

The statistical tests resulted in the analysis that there was no significant difference between the mean of nasopharynx width value of CLP postpalatoplasty children with normal children (see Tables 5 and 6). This result was consistent with the study conducted by Coccaro et al. ${ }^{16}$, which explained that there have been non-significant nasopharynx abnormalities in CLP children after palatoplasty age 5 to 7 years than normal children. The difference was only slight and not significant compared to children under and over the age of 5 to 7 years who have different growth rates with normal children. ${ }^{16}$

Radiographic examination (retrieval of lateral cephalometric radiograph photo data) also influences the results of the study. It may be possible to influence the results of the research at the time of photographic capture of the lateral cephalometry was head posture, tongue, and pharyngeal conditions. Respiratory inspiration and expiration during lateral cephalometric tracing were said to affect upper airway exposure. ${ }^{17,18}$

Posterior crossbite examination can be known by the study model. The study model was obtained from children with CLP post-palatoplasty and normal children. The scoring results showed that all children with CLP post palatoplasty had crossbite, either anterior crossbite or posterior crossbite. Distribution of crossbite in children with CLP post palatoplasty was $42.9 \%$ was poor criteria, $35.7 \%$ was moderate criteria, $14.3 \%$ was Very Poor criteria, and at least was Good criteria of $7.1 \%$ (see table 3). This indicates that mean children with CLP post-palatoplasty was included in the poor criteria.

Furthermore scoring results that illustrate the presence of posterior crossbite was present in all children with CLP post-palatoplasty. The distribution level of severity of posterior crossbite on children with CLP post-palatoplasty CLP was $42.9 \%$ in the Good criteria, $35.7 \%$ was Moderate criteria, as many as $14.3 \%$ was the Poor criteria, and at least on was the Very Good criteria of 7.1\% (see table 4). This was consistent with the study of Heidbuchel et al which states that children with CLP post-palatoplasty have the dimensions of the maxilla arch like the width and depth of the arch, generally larger at birth but smaller at the time of primary teeth. As a result of decreasing the width of the maxilla arch, it results in a crossbite which was the beginning of frequent malocclusion in children with CLP post-palatoplasty. ${ }^{19}$

The results showed that the frequency of posterior crossbite was reported to be 30 to 97 percent. The same thing in this study found that all samples have posterior crossbites and the severity of posterior crossbites of children with CLP post-palatoplasty were included in the Good criteria. The study suggesting the possibility of a significant posterior crossbite on examination of infants who have not treat with surgery. $88 \%$ had posterior crossbite in the period of the first tooth and $91 \%$ in mixed dentition later. Reisser et al studies suggest that the CLP group of postpalatoplasty children was also posterior crossbite at the age of 5 years. ${ }^{20}$

Posterior crossbite in the period of deciduous teeth was often associated with bilateral maxillary 
contractions, and posterior crossbite will be accompanied by lateral functional movements, resulting in an unbalanced jaw movement. ${ }^{20}$ If left unchecked, other disorders (dental and skeletal) which were worse in the future.

The period of growth and development was a very good time to prevent posterior crossbite abnormalities as early as possible. Almost all children with CLP post-palatoplasty in the study experienced posterior crossbite. Genetic and environmental factors may contribute to the development of posterior crossbite abnormalities. Posterior crossbite did not threaten life, but the problem was important communities can be prevented or intercepted. A posterior crossbite disorder should be treated as soon as the abnormality is diagnosed, as a posterior crossbite can cause growth problems and skeletal aberrations if no treatment is performed. ${ }^{21}$

The impact of posterior crossbite found at the time of the deciduous teeth will result in the erosion of eruption of teeth remain in one place, unbalanced head basal bone development caused by disharmony of maxillary and mandibular growth or there may also be a mismatch of the width of the upper and lower jaws transversally resulting in the closing of the lower jaw in the lateral direction. The facial oral extras will appear to be more asymmetry in CLP children after palatoplasty. ${ }^{1}$

A good dental relationship was an important parameter in craniofacial growth and indicator of success in the treatment of cleft palate. Good craniofacial growth was an important key to the treatment outcomes of children with CLP postpalatoplasty. Good craniofacial growth results in good dental arch relationships and treatments can be performed either conventionally or without surgical correction. ${ }^{10}$

\section{CONCLUSION}

Based on the results of this study it can be concluded that there is no difference in the average value of nasopharyngeal area between children with cleft lip and palate after palatoplasty with normal children. The severity of posterior crossbite in children with CLP post-palatoplasty is included in the results of the study show that the earlier children suffer from CLP and have received palaoplasty treatment, the child has not suffered much malocclusion, so early treatment is more advisable to prevent the occurrence of more severe malocclusions in the future the Good criteria.

\section{REFERENCES}

1. Jones JE, Sadove AM, Dean JA, Huebener DV. Multidiciplinary Team Approach to Cleft Lip and Palate Management. In: McDonald R, Avery D, Dean J. McDonald and Avery Dentistry for the Child and Adolescent. $9^{\text {th }}$ ed. St. Louis: Mosby-Elsevier; 2011. pp. 614-37.

2. Reiser E. Cleft Size and Maxillary Arch Dimensions in Unilateral Cleft Lip and Palate and Cleft Palate [dissertation]. Uppsala: Uppsala Universitet; 2011. pp. 1-72.

3. Irawan H, Kartika I. Technique of labiopalatoschizis surgery. CDK215. 2014; 41(4): 304-8.

4. Lesmana RSN. Prevalensi Celah Bibir dan Langit-Langit Di Yayasan Pembina Penderita Celah Bibir dan Langit-Langit (YPPCBL) Bandung Tahun 2008-2012 [minor thesis]. Bandung: Maranatha Christian University; 2013.

5. Friel MT, Starbuck JM, Ghoneima AM, Murage K, Kula KS, Tholpady S, et al. Airway obstruction and the unilateral cleft lip and palate deformity. Ann Plast Surg. 2015; 75(1): 37-43. DOI: 10.1097/SAP.0000000000000027

6. Shi B, Losee JE. The impact of cleft lip and palate repair on maxillofacial growth. Int J Oral Sci. 2015; 7(1): 14-17. DOI: 10.1038/ ijos.2014.59

7. Wermker $\mathrm{K}$, Jung $\mathrm{S}$, Joos $\mathrm{U}$, Kleinheinz J. Nasopharyngeal development in patients with cleft lip and palate: A retrospective casecontrol study. Int J Otolaryngol. 2012; 2012: 458507. DOI: $10.1155 / 2012 / 458507$

8. Gohilot A, Pradhan T, Keluskar KM. Cephalometric evaluation of adenoids, upper airway, maxilla, velum length, need ratio for determining velopharyngeal incompetency in subjects with unilateral cleft lip and palate. J Indian Soc Pedod Prev Dent. 2014; 32(4): 297 303. DOI: $10.4103 / 0970-4388.140950$

9. Grewal N, Godhane AV. Lateral cephalometry: A simple and economic clinical guide for assessment of nasopharyngeal free airway space in mouth breathers. Contemp Clin 
Dent. 2010; 1(2): 66-9. DOI: 10.4103/0976237X.68589

10. Wangsrimongkol T, Jansawang W. The assessment of treatment outcome by evaluation of dental arch relationship in cleft lip/palate. J Med Assoc Thai. 2010; 93(Suppl 4): S100-6.

11. de Vasconcellos Vilella $O$, de Souza Vilella $B$, Karsten A, Filho DI, Monteiro AA, Koch HA, et al. Evaluation of the nasopharyngeal free airway space based on lateral cephalometric radographs and endoscopy. Orthod. 2004; 1(3): 1-9.

12. Tothill C, Mossey PA. Assessment of arch constriction in patients with bilateral cleft lip and palate and isolated cleft palate: A pilot study. Eur J Orthod. 2007; 29(2): 193-7. DOI: 10.1093/ejo/cjm006

13. Leslie EJ, Marazita ML. Genetics of cleft lip and cleft palate. Am J Med Genet C Semin Med Genet. 2013; 163(4): 246-58. DOI: 10.1002/ ajmg.c.31381

14. Carroll K, Mossey PA. Anatomical variations in clefts of the lip with or without cleft palate. Plast Surg Int. 2012; 2012: 542078. DOI: 10.1155/2012/542078

15. Koh KS, Kim SC, Oh TS. Management of velopharyngeal insufficiency using double opposing z-plasty in patients undergoing primary two-flap palatoplasty. Arch Plast Surg. 2013; 40(2): 97-103. DOI: 10.5999/ aps.2013.40.2.97
16. Coccaro PJ, Pruzansky S, Subtelny JD. Nasopharyngeal growth. Cleft Palate J. 1967; 4(3): 214-27.

17. Gupta S, Subrahmanya RM. Assessment of orophraryngeal width in individuals with different facial skeletal patterns. Nitte Univ J Health Sci. 2014; (4)2: 34-38. DOI: 10.1055/s0040-170376

18. Mislik B, Hanggi MP, Signorelli L, Peltomaki TA, Patcas R. Pharyngeal airway dimensions: A cephalometric, growth-study-based analysis of physiological variation in children age 6-17. Eur J Orthod. 2014; 36(3): 331-9. DOI: 10.1039/ejo/cjt068

19. Heidbuchel KL, Kuijpers-Jagtman $A M$, Kramer GJ, Prahl-Andersen B. Maxillary arch dimensions in bilateral cleft lip and palate from birth until four years of age in boys. Cleft Palate Craniofac J. 1998; 35(3): 233-9. DOI: 10.1597/1545-1569_1998_035_0233 madibc 2.3co 2

20. Reiser E, Skoog V, Gerdin B, Andlin-Sobocki A. Association between cleft size and crossbite in children with cleft palate and unilateral cleft lip and palate. Cleft Palate Craniofac J. 2010; 47(2): 175-181. DOI: 10.1597/08-219_1

21. Alam MK, Kajii TS, lida J. Spectrum of Factors Affecting Dental Arch Relationships in Japanese Unilateral Cleft Lip and Palate Patients. In: Bourzgui F. Orthodontics - Basic Aspect and Clinical Considerations. London: InTech Open Ltd.; 2012. pp. 301-323. 